\title{
PŘEHLED AKTUÁLNÍ JUDIKATURY II/2020
}

\author{
FRANTIŠEK KASL, JAKUB KLODWIG, IVANA KUDLÁČKOVÁ, PAVEL \\ LOUTOCKÝ, JAKUB MÍŠEK, TEREZA NOVOTNÁ, JURAJ VIVODA, \\ JAKUB VOSTOUPAL, VERONIKA ŽOLNERČÍKOVÁ
}

\section{PRÁVO DUŠEVNÍHO VLASTNICTVÍ}

\author{
AUTORÁDIO JAKO SDĚLOVÁNÍ DÍLA VEŘEJNOSTI \\ Soud: $\quad$ Soudní dvůr Evropské unie \\ Věc: $\quad$ C-753/18 (Stim a SAMI) \\ Datum: $\quad$ 2. 4. 2020 \\ Dostupnost: curia.europa.eu
}

V původním sporu rozhodovaly švédské soudy ve dvou případech, které byly poté před Soudním dvorem spojeny $\mathrm{v}$ jeden. $\mathrm{V}$ prvním případě se organizace Stim (švédská organizace pro správu autorských práv hudebních skladatelů a jejich vydavatelů) domáhala u soudu zaplacení náhrady škody za porušení autorských práv od společnosti Fleetmanager, která zprostředkovává krátkodobý pronájem vozidel vybavených radiopřijímačem. $\mathrm{V}$ druhém případě se společnost NB domáhala $\mathrm{u}$ soudu navrácení poplatků za užívání zvukových záznamů, které platila organizaci SAMI (švédská organizace pro správu práv souvisejících s autorským právem výkonných umělců) taktéž za zprostředkování krátkodobého pronájmu vozidel vybavených radiopřijímači. ${ }^{1}$

Oba případy byly řešeny před švédskými obecnými soudy. $V$ obou případech odvolací soudy nevyhověly organizaci Stim jako žalobkyni v prvním

1 Body 13, 14 a 16 anotovaného rozhodnutí. 
případě a organizaci SAMI jako žalované $\mathrm{v}$ druhém případě a organizace tedy podaly kasační stížnosti ke švédskému Nejvyššímu soudu. ${ }^{2}$

Nejvyšší soud ve Švédsku tedy předložil Soudnímu dvoru dvě předběžné otázky: 1) zda se jedná o sdělování veřejnosti v př́ípadě krátkodobého pronájmu vozidel s radiopřijímači a 2) jaký je v takovém případě význam objemu činnosti pronajímání vozidel a zejména doby trvání pronájmu. ${ }^{3}$

Sdělování autorského díla veřejnosti je $\mathrm{v}$ unijním právu upraveno zejména bodem 27 odůvodnění a čl. 3 odst. 1 směrnice 2001/29 a čl. 8 směrnice 2006/115 týkajících se sdělování veřejnosti, které Soudní dvůr v tomto případě aplikoval.

Soudní dvůr se zabýval nejprve první otázkou a tedy tím, zda krátkodobý pronájem vozidel $s$ radiopřijímači představuje sdělování díla veřejnosti. Z ustálené judikatury Soudního dvora vyplývá, že pojem sdělování veřejnosti představuje dva prvky - „sdělováni“ a „veřejnosti“ - které musí být splněny kumulativně. ${ }^{4}$ Sdělování je upřesněno v bodu 27 odůvodnění směrnice 2001/29 tak, že „pouhé poskytnutí fyzického zař̌zení pro umožnění nebo uskutečnění sdělování není samo o sobě sdělováním ve smyslu této směrni$c e^{\text {", }}$ což je právě případ poskytnutí radiopřijímače v pronajatém autě, kde se jedná spíše o dodání než-li sdělování. Soudní dvưr tedy dospěl k tomu, že první kumulativní podmínka není splněna a o sdělování veřejnosti se tedy nejedná, $\mathrm{z}$ tohoto důvodu se již nezabýval druhou otázkou. ${ }^{5}$

Soudní dvưr tedy došel $\mathrm{k}$ závěru, že pronájem vozidel opatřených radiopřijímači bez dalšího nepředstavuje sdělování veřejnosti ve smyslu příslušné právní úpravy.

Body 15 a 17 anotovaného rozhodnutí.

Bod 18 anotovaného rozhodnutí.

Bod 30 anotovaného rozhodnutí.

Body 33 až 36 anotovaného rozhodnutí. 


\section{OCHRANA FUNKČNÉHO TVARU VÝROBKU AUTORSKÝM PRÁVOM}

$\begin{array}{ll}\text { Soud: } & \text { Súdny dvor Európskej únie } \\ \text { Věc: } & \text { C-833/18 (Brompton Bicycle) } \\ \text { Datum: } & \text { 11. 6. } 2020 \\ \text { Dostupnost: } & \text { curia.europa.eu }\end{array}$

Spoločnost̉ Brompton Bicycle Ltd (Brompton) založená pánom SI predáva skladací bicykel, ktorého tvar navrhnutý v roku 1987 umožňuje tri rozličné polohy. ${ }^{6}$ Doba platnosti patentu už uplynula. Spoločnosṫ Chedech/Get2Get (Get2Get) predáva vizuálne vel'mi podobný a rovnako polohovatel'ný bicykel. Pán SI a Brompton sa obrátili na belgický súd s tvrdením, že bicykle Get2Get porušujú autorské právo Brompton a osobnostné práva pána SI a žiadali, aby prikázal ich stiahnutie z predaja. Get2Get tvrdí, že vonkajšia úprava ich bicykla je podmienená technickým riešením, aby bicykel mohol mat želané polohy. Brompton namieta, že rovnakú polohovatel'nost možno dosiahnut aj inými tvarmi bicykla, a preto jeho tvar môže byt chránený autorským právom.

Belgický súd uvádza, že v oblasti práva dizajnov Súdny dvor Európskej únie (SDEÚ) už rozhodol, že na posúdenie toho, či sú znaky vonkajšej úpravy výrobku dané výlučne technickou funkciou tohto výrobku, treba určit, či je táto funkcia jediným faktorom, ktorý určuje tieto znaky, pričom existencia alternatívnych dizajnov nie je $\mathrm{v}$ tejto súvislosti rozhodujúca. Belgický súd sa preto prejudiciálnou otázkou SDEÚ pýta, či sa čl. 2 až 5 smernice 2001/29 majú vykladat (podobne) v tom zmysle, že autorskoprávna ochrana, ktorú stanovujú, sa uplatňuje na výrobok, ktorého tvar je minimálne sčasti nevyhnutný na dosiahnutie technického výsledku.

6 Ide o zloženú polohu, rozloženú polohu a prostrednú polohu umožňujúcu udržat bicykel na zemi v rovnováhe.

7 Smernica Európskeho parlamentu a Rady 2001/29/ES z 22. mája 2001 o zosúladení niektorých aspektov autorských práv a s nimi súvisiacich práv v informačnej spoločnosti. Podla článkov 2 až 5 smernice 2001/29 sú autori chránení proti rozmnožovaniu, verejnému prenosu a verejnému šíreniu ich diel bez ich súhlasu. 
SDEÚ uvádza, že na predmet spíňajúci podmienku originality sa môže vztahovat' autorskoprávna ochrana, aj ked' jeho zhotovenie bolo určené technickými požiadavkami, pokial toto určenie nebránilo autorovi vtisnút do daného predmetu vlastnú osobnost' ako prejav jeho slobodných a tvorivých rozhodnutí. Pokial' vyjadrenie zložiek predmetu je predurčené ich technickou funkciou, jednotlivé spôsoby realizácie danej myšlienky sú natol'ko obmedzené, že myšlienka a jej vyjadrenie splývajú.

Podla SDEÚ sa čl. 2 až 5 smernice 2001/29 majú vykladat v tom zmysle, že v nich stanovená autorskoprávna ochrana sa uplatní na výrobok, ktorého tvar je minimálne sčasti nevyhnutný na dosiahnutie technického výsledku, pokial' tento výrobok je originálnym dielom, ktoré je výsledkom duševnej tvorby $\mathrm{v}$ rozsahu, $\mathrm{v}$ akom výberom tohto tvaru vyjadril jeho autor svoju tvorivú schopnosṫ originálnym spôsobom vykonaním slobodných a tvorivých rozhodnutí tak, že uvedený tvar odráža jeho osobnosṫ. Splnenie týchto podmienok prináleží overit vnútroštátnemu súdu s ohl’adom na skutočnosti veci samej.

Autor: JVi

\section{POJEM „ADRESA“ V SMERNICI O VYMOŽITELNNOSTI PRÁV DUŠEVNÉHO VLASTNÍCTVA SA NEVZŤAHUJE NA E-MAILOVÚ ADRESU, TELEFÓNNE ČÍSLO ANI IP ADRESU OSOBY, KTORÁ NAHRALA CHRÁNENÉ DIELO NA PLATFORMU}

Soud: $\quad$ Súdny dvor Európskej únie

Věc: $\quad$ C-264/19 (Constantin Film Verleih)

Datum: $\quad$ 9. 7. 2020

Dostupnost: curia.europa.eu

Spoločnost Constantin Film Verleih (Constantin) má v Nemecku výlučné práva na používanie filmov, ktoré boli neoprávnene nahraté na YouTube. Constantin od YouTube žiadala identifikačné údaje o používatel'och, ktorí filmy nahrali. Ked’že na prvom stupni získala len fiktívne mená používatel'ov, žiadala aby YouTube poskytla aj ich e-mailové adresy, telefónne čísla a IP adresy. Krajinský súd v Nemecku žalobu Constantin 
zamietol, avšak Vyšší krajinský súd na základe jej odvolania zaviazal YouTube poskytnút e-mailové adresy používatel’ov. Vo zvyšnej časti odvolanie zamietol.

Súdny dvor Európskej únie (SDEÚ) na základe prejudiciálnej otázky Spolkového súdneho dvora v Nemecku, na ktorý podali Constantin aj YouTube mimoriadny opravný prostriedok, posudzoval, či sa má čl. 8 ods. 2 písm. a) smernice $2004 / 48^{8}$ vykladat v tom zmysle, že pojem „adresa“ sa vztahuje, pokial' ide o používatel’a, ktorý nahral súbory, aj na jeho e-mailovú adresu, telefónne číslo a IP adresu použitú na ich nahratie alebo pri poslednom prístupe na používatel'ský účet.

Podla čl. 8 smernice 2004/48 musia členské štáty zabezpečit, aby súdy mohli nariadit online platforme, aby poskytla mená a adresy osoby, ktorá nahrala film bez súhlasu nositela práv. Napriek tomu, že ide o minimálnu harmonizáciu, a teda čl. 8 smernice 2004/48 sa obmedzuje len na presne vymedzené informácie, podla SDEÚ to nebráni členským štátom priznat aj širšie právo na informácie, ak zabezpečia rovnováhu medzi právami nositel’ov práv a právami používatel’ov.

Avšak kedže smernica 2004/48 neodkazuje na právo členských štátov na účely vymedzenia svojho zmyslu a významu, pojem „adresa“ predstavuje pojem práva Únie, ktorý sa má vykladą jednotne v celej Únii. Podla SDEÚ sa v bežnom jazyku tento pojem vztahuje len na poštovú adresu a prípravné práce $\mathrm{k}$ smernici nenaznačujú, že by sa mal vztahovat na e-mailovú adresu, telefónne číslo alebo IP adresu. Kontext, v ktorom sa tento pojem používa podla SDEÚ potvrdzuje takýto výklad a je v súlade $s$ ciel'mi smernice.

Podla SDEÚ sa teda pojem „adresa“ v čl. 8 ods. 2 písm. a) smernice 2004/48/ES nevztahuje, pokial' ide o používatel’a, ktorý nahral súbory porušujúce právo duševného vlastníctva, na jeho e-mailovú adresu, telefónne číslo, ani na IP adresu použitú na nahratie týchto súborov alebo pri poslednom prístupe na používatel’ský účet.

Autor: JVi

8 Smernica Európskeho parlamentu a Rady 2004/48/ES z 29. apríla 2004 o vymožitel’nosti práv duševného vlastníctva. 


\section{SOUKROMÍ A OSOBNÍ ÚDAJE}

\section{PŘÍPUSTNOST ČASOVĚ NEOMEZENÉHO UCHOVÁVÁNÍ FOTOGRAFIÍ, OTISKŮ PRSTŮ A DNA PROFILŮ ODSOUZENÝCH}

Soud: $\quad$ Evropský soud pro lidská práva

Věc: Z Z Z Z $\quad$ Zádost 45245/15 (Gaughran proti Velké Británii)

Datum: $\quad$ 13. 6. 2020

Dostupnost: hudoc.echr.coe.int

Fergus Gaughran, občan Velké Británie, byl v roce 2008 zatčen za řízení v opilosti, byly mu odebrány otisky prstů, vzorek DNA (ze kterého byl vytvořen DNA profil) a byl vyfocen do policejní databáze. Jelikož se k činu doznal, soud mu uložil pokutu a zákaz řízení motorových vozidel na 12 měsíců. Dva měsíce po doznání činu se stěžovatel dovolával zničení biometrických údajů s tím, že jejich další uchovávání je nezákonné, policie však jeho žádost s odkazem na účinnou legislativu zamítla. ${ }^{9}$

Vrchní soud Severního Irska, před který se případ následně dostal, shledal, že uchovávání biometrických údajů stěžovatele představuje legitimní a proporcionální zásah do práva na soukromí. ${ }^{10}$ Toto následně potvrdil i Nejvyšší soud Velké Británie, který zdůraznil, že fotografie stěžovatele je uchovávána pouze v lokální databázi, která neumožňuje mapování fotografií, a další údaje představují pouze malý zásah do soukromí. ${ }^{11}$

Stěžovatel se tedy obrátil na Evropský soud pro lidská práva s žádostí o určení, zda časově neomezené uchovávání biometrických údajů odsouzených představuje zásah do práva na soukromí podle Evropské úmluvy o lidských právech. ${ }^{12}$

Článek 8 Úmluvy přiznává každému právo na respekt k soukromému a rodinnému životu. Toto právo může být omezeno pouze na základě záko-

\footnotetext{
Body 6 až 9 anotovaného rozhodnutí.

10 Body 10 a 11 anotovaného rozhodnutí.

11 Body 12 až 19 anotovaného rozhodnutí.

12 Bod 58 anotovaného rozhodnutí.
} 
na a pouze $\mathrm{v}$ případech, kdy je to $\mathrm{v}$ demokratické společnosti nezbytné pro účely (mimo jiné) předcházení trestné činnosti. ${ }^{13}$

Skutečnost, že uchovávání představuje zásah do práva na soukromí, byla nesporná i mezi stranami. ${ }^{14}$ Při hodnocení legitimity zásahu Soud konstatoval, že primární problém není v neomezené době uchování dat, ${ }^{15}$ ale v absenci mechanismů, které by zohledňovaly pachatelův čin, věk, potřebu pro uchování údajů, dobu uplynulou od spáchání činu, zahlazení odsouzení, pachatelovu osobnost a chování a které by umožňovaly pachateli dosáhnout výmazu údajů. ${ }^{16}$ Čím vyšší doba uchování údajůn, tím spíše musí být nastaveny tyto mechanismy. ${ }^{17}$ Problém Soud dále spatřoval i v tom, že fotografie stěžovatele se sice nacházela v lokální databázi, ale bylo ji možné nahrát do národní policejní databáze, která již umožňovala využívat technologie rozeznávání obličejů, což byl pokrok, který se udál mezi rozhodnutím Nejvyššího soudu a rozhodováním Evropského soudu pro lidská práva. ${ }^{18}$

Soud dospěl k závěru, že nerozlišující a neomezeně dlouhé uchovávání údajů představuje neospravedlnitelný zásah do práva na soukromí podle Úmluvy. ${ }^{19}$ Zajímavým bodem rozhodnutí je mimo jiné i upozornění, že pokud stát přistoupí k využívání neomezené doby uchování údajů, nelze ignorovat (i potenciální/budoucí) rozvoj technologií, které mohou zásah prohloubit. $^{20}$

Autor: JVo

13 Článek 8 Evropské úmluvy o lidských právech.

${ }^{14}$ Soud při posuzování navázal na př́pad S. a Marper proti Velké Británii, kde se řešilo uchovávání údajů osob neodsouzených. Viz body 60 a 63 až 70 anotovaného rozhodnutí.

15 Patrné zvláště na rozhodnutích Peruzzo a Martens proti Německu zde dne 4. 6. 2013 a Aycaquer proti Francii ze dne 22. 6. 2017, více viz bod 87 anotovaného rozhodnutí.

16 Resp. policie měla $\mathrm{k}$ výmazu přistupovat $\mathrm{v}$ natolik výjimečných případech, že tento postup soud označil až za hypotetický, viz bod 94 anotovaného rozhodnutí.

17 Bod 94 anotovaného rozhodnutí.

18 Bod 68 anotovaného rozhodnutí.

19 A to i navzdory tomu, že Soud přiznal státům širší „pole působnosti“ při zásazích do práva na soukromí odsouzených. Viz bod 96 anotovaného rozhodnutí.

${ }^{20} \mathrm{~V}$ tomto případě šlo o zmíněný značný pokrok v oblasti technologií rozeznávání obličejů, který se udál mezi rozhodnutím Nejvyššího soudu a Evropského soudu pro lidská práva. Viz bod 68 anotovaného rozhodnutí. 


\section{ZASÍLÁNÍ OBCHODNÍCH SDĚLENÍ}

Soud: $\quad$ Nejvyšší správní soud České republiky

Věc: $\quad 1$ As $136 / 2019-38$

Datum: $\quad$ 16. 6. 2020

Dostupnost: nssoud.cz

V roce 2014 společnost www.scio.cz, s. r. o. (dále jen „Scio“), zajištovala pro Masarykovu univerzitu příímací zkoušky na Ekonomicko-správní fakultu. Bez souhlasu uchazečů přitom rozeslala na tři tisíce emailových adres, které uchazeči o studium uvedli do přihlášky ke studiu, nabídku absolvovat Národní srovnávací zkoušky (dále jen „NSZ“), jako alternativní způsob pro přijetí. $^{21}$

Tímto podle Úřadu pro ochranu osobních údajů (dále jen „ÚOOÚ“) Scio spáchalo správní delikt šíření obchodního sdělení bez souhlasu adresáta, za což vyměřil pokutu 450 000,- Kč. Ačkoliv Scio podalo proti tomuto rozhodnutí rozklad, předseda ÚOOÚ jej zamítl a rozhodnutí potvrdil. Scio podalo žalobu k Městskému soudu v Praze, který shledal, že výrok rozhodnutí ÚOOÚ obsahuje dostatečně konkrétní vymezení skutkových okolností deliktu a žalobu zamítl, ${ }^{22}$ načež podala Scio kasační stížnost k Nejvyššímu správnímu soudu (dále jen „NSS“).

NSS se kromě jiného zabýval zejména výkladem pojmu obchodní sdělení, a tedy zda lze zaslaný informativní email obsahující informace o NSZ považovat za obchodní sdělení. ${ }^{23}$

Definice obchodních sdělení je obsažena v § 2 písm. f) zákona o některých službách informační společnosti, přičemž pravidla pro zasílání obchodních sdělení upravuje $\S 7$ a případnou sankci $\S 11$ odst. 1 písm. a) tamtéž.

NSS považoval za nesporné, že email byl „sdělením“ a že Scio jej poslalo při výkonu své podnikatelské činnosti, a tudíž jedinou spornou otázkou zů-

\footnotetext{
21 Bod 1 anotovaného rozhodnutí.

22 Bod 4 anotovaného rozhodnutí.

23 Body 25-37 anotovaného rozhodnutí.
} 
stává, zda byl email určen $\mathrm{k}$ „přimé či nepřimé podpoře zboži či služeb stěžovatelky“. ${ }^{24}$ Scio namítalo, že jejím záměrem nebylo podpořit své služby, nýbrž informovat uchazeče o podmínkách pro přijetí ke studiu dle § 49 odst. 5 zákona o vysokých školách. ${ }^{25}$ NSS se však s tímto tvrzením neztotožnil a uvedl, že není povinností vysokých škol informovat o NSK a ani není rozhodné, jaké byly vnitřní pohnutky Scia, jelikož pojem obchodního sdělení je pojmem objektivním. ${ }^{26}$ Proto pokud je hlavní podnikatelskou činnosti Scia testování a zpracování NSZ, tak sdělení rozeslané elektronicky na adresy uchazečů o studium na vysoké škole, informující uchazeče o možnosti absolvovat Sciem organizovanou NSK, má nepochybně za cíl mj. ekonomický prospěch $\operatorname{Scia}^{27}$ a je tedy obchodním sdělením.

Rozhodnutí ve svém důsledku posiluje ochranu osob před zasíláním obchodních sdělení, jelikož definici obchodního sdělení vykládá objektivně.

Autor: JK

\section{PŘEDÁVÁNÍ OSOBNÍCH ÚDAJŮ DO ZAHRANIČÍ}

Soud: $\quad$ Soudní dvůr Evropské unie

Věc: $\quad$ C-311/18 (Schrems II)

Datum: $\quad$ 16. 7. 2020

Dostupnost: curia.europa.eu

Tento rozsudek navazuje na rozhodnutí SDEU ve věci Schrems, ${ }^{28}$ ve kterém SDEU zrušil rozhodnutí Evropské komise Safe Harbour. ${ }^{29} \mathrm{~V}$ přeformulované stížnosti se Schrems opět domáhal zákazu předávání jeho osobních údajů společností Facebook Ireland z EU jeho mateřské společnosti Facebook Inc.

24 Bod 28 anotovaného rozhodnutí.

25 Bod 32 anotovaného rozhodnutí.

26 Bod 33 anotovaného rozhodnutí.

27 Bod 36 anotovaného rozhodnutí.

28 Rozsudek SDEU ze dne 6. října 2015, Schrems I (C-362/14, EU:C:2015:650).

29 Rozhodnutí Komise ze dne 26. července 2000 podle směrnice Evropského parlamentu a Rady 95/46/ES o odpovídající ochraně poskytované podle zásad „bezpečného př́ístavu“ a s tím souvisejících „často kladených otázek“ vydaných Ministerstvem obchodu Spojených států (Úř. věst. 2000, L 215, s. 7; Zvl. vyd. 16/01, s. 119), 
sídlící v USA z důvodu př́liš širokých pravomocí amerických zpravodajských služeb. ${ }^{30}$

$\mathrm{V}$ reakci na novou stižñnost Schremse zveřejnila komisařka ${ }^{31} \mathrm{v}$ květnu 2016 své předběžné závěry a navrhla Vrchnímu soudu, ${ }^{32}$ aby předložil SDEU předběžnou otázku. Vrchní soud návrhu vyhověl a předložil SDEU jedenáct předběžných otázek. ${ }^{33}$

Předmětem předběžných otázek byly různé dílčí aspekty oprávněnosti předávání osobních údajů z EU do USA na základě rozhodnutí komise Privacy Shield ${ }^{34}$ a na základě standardních smluvních doložek dle rozhodnutí SSD $^{35}$. Středobodem úvah bylo, zda jsou americké zpravodajské služby oprávněny zpracovávat osobní údaje občanů EU předávané do USA a zda to př́ípadně způsobuje nedostatečnou úroveň ochrany osobních údajů $\mathrm{v}$ USA.

Předmětem zkoumání se stal zejména americký výkonný dekret $12333,{ }^{36}$ prezidentská politická směrnice $28^{37}$ a $\S 702$ FISA, ${ }^{38}$ povolující některé sledovací programy (např. PRISM, UPSTREAM) ${ }^{39}$. Z evropské legislativy je dů-

\footnotetext{
30 Bod 55 anotovaného rozhodnutí.

31 Data Protection Commissioner, neboli komisař pro ochranu údajů, Irsko.

32 High Court, Irsko.

33 Bod 68 anotovaného rozhodnutí.

34 Prováděcí rozhodnutí Komise (EU) 2016/1250 ze dne 12. července 2016 podle směrnice Evropského parlamentu a Rady 95/46 o odpovídající úrovni ochrany poskytované štítem EU-USA na ochranu soukromí (Úř. věst. 2016, L 207, s. 1).

35 Rozhodnutí Komise 2010/87/EU ze dne 5. února 2010 o standardních smluvních doložkách pro předávání osobních údajů zpracovatelům usazeným ve třetích zemích podle směrnice Evropského parlamentu a Rady 95/46 (Úř. věst. 2010, L 39, s. 5), ve znění prováděcího rozhodnutí Komise (EU) 2016/2297 ze dne 16. prosince 2016 (Úř. věst. 2016, L 344, s. 100).

36 Executive Order 12333 ze dne 4. 12. 1981.

37 Presidential Political Directive ze dne 17. ledna 2014.

38 Foreign Intelligence Surveillance Act (zákon o zabezpečování informací o činnostech cizí moci).

39 Bod 109 anotovaného rozhodnutí.
} 
ležitý zejména čl. 7,8 a 47 Listiny, ${ }^{40}$ čl. 25,26 a 28 směrnice, ${ }^{41}$ čl. 45 GDPR, ${ }^{42}$ rozhodnutí SSD a rozhodnutí Privacy Shield. ${ }^{43}$

V projednávaném rozsudku bylo zpochybněno tvrzení, které Komise uvedla v rozhodnutí Privacy Shield a sice, že zřízení mechanismu ombudsmana může zhojit nedostatky zjištěné ve sledovacích programech, jejichž základem je § 702 FISA, PPD-28 a EO 12333, které nepřiznávají subjektům údajů práva vymahatelná vůči orgánům USA před soudy, takže subjekty údajů postrádají právo na účinný prostředek nápravy. ${ }^{44}$ Takový nedostatek v soudní ochraně proti zásahům spojeným se zpracováním osobních údajů zpravodajskými programy, způsobuje že rozhodnutí Privacy Shield je neslučitelné s čl. 45 odst. 1 GDPR ve spojení s články 7, 8 a 47 Listiny, a z toho důvodu je neplatné. Současně však SDEU neodhalil žádnou skutečnost, která by mohla mít dopad na platnost rozhodnutí SSD, a tudíž je možné předávat osobní údaje do třetích států včetně USA na základě standardních smluvních doložek, ${ }^{45}$ pokud existují vhodné záruky, vymahatelná práva a účinná právní ochrana, zajištující subjektům údajů rovnocennou úroveň ochrany jako $\mathrm{v}$ EU.

Tento velice významný rozsudek zneplatnil rozhodnutí Privacy Shield, na jehož základě bylo možné předávat osobní údaje z EU certifikovaným společnostem sídlícím $\mathrm{v} U \mathrm{UA}$, a současně ponechal možnost předávat osobní údaje do USA na základě standardních smluvních doložek.

Autor: JK

\footnotetext{
40 Listiny základních práv Evropské unie

41 Směrnice Evropského parlamentu a Rady 95/46/ES ze dne 24. ř́ijna 1995 o ochraně fyzických osob v souvislosti se zpracováním osobních údajů a o volném pohybu těchto údajů.

42 Nařízení Evropského parlamentu a Rady (EU) 2016/679 ze dne 27. dubna 2016 o ochraně fyzických osob v souvislosti se zpracováním osobních údajů a o volném pohybu těchto údajů a o zrušení směrnice 95/46/ES (obecné nařízení o ochraně osobních údajů).

43 Rozhodnutí Komise (EU) 2016/1250 ze dne 12. července 2016 podle směrnice Evropského parlamentu a Rady 95/46 o odpovídající úrovni ochrany poskytované štítem EU-USA na ochranu soukromí (Úř. věst. 2016, L 207, s. 1).

44 Bod 192 anotovaného rozhodnutí.

45 Bod 149 anotovaného rozhodnutí.
} 


\section{SPZ JE OSOBNÍ ÚDAJ}

Soud: $\quad$ Nejvyšší správní soud

Věc: $\quad 1$ As $387 / 2019-56$

Datum: $\quad$ 13. $\quad 2020$

Dostupnost: nssoud.cz

Městský soud Hořovice poskytl třetí osobě informace ze správního spisu žalobce $\mathrm{k}$ řízení o přestupku. Žalobce se u Krajského soudu v Praze domáhal žalobou určení nezákonného zásahu vzniklého předmětným jednáním, kterým bylo poskytnutí jeho jména a příjmení, registrační značky vozidla, fotografie vozidla, popisu jeho jednání a údaji o jeho zmocněnci třetí osobě. Krajský soud uvedl, že registrační značku vozidla lze k majiteli či provozovateli přiřadit pouze na základě údajů z registru silničních vozidel, který není veřejným seznamem a z pouhé informace o registrační značce není možné žalobce jednoznačně určit. ${ }^{46}$ Žalobce podal kasační stížnost s argumentem, že registrační značka je osobním údajem v případě, že vlastníkem a provozovatelem motorového vozidla je fyzická osoba.

Nejvyšší správní soud tedy posuzoval, zda poskytnuté informace (především registrační značka) jsou osobním údajem, které podle § 8a zákona o svobodném přístupu $\mathrm{k}$ informacím lze poskytnout jen v souladu s právními předpisy upravujícími jejich ochranu a zda poskytnutím těchto údajů došlo v projednávaném případě $\mathrm{k}$ nezákonnému zásahu či nikoli. ${ }^{47}$

Nejvyšší správní soud při posuzování povahy registrační značky vycházel z tzv. objektivního pojetí osobních údajů. Uvedl, že informace je osobním údajem, existují-li jakékoliv osoby nebo orgány, které by daný subjekt údajů dokázaly na základě předmětné informace (ve spojení s jimi dostupnými doplňujícími údaji) identifikovat. ${ }^{48} \mathrm{~S}$ odkazem na judikaturu členských států Evropské unie i svoji vlastní Nejvyšší správní soud uvedl, že pokud je vlastník nebo provozovatel vozidla fyzickou osobou, tak je iden-

\footnotetext{
46 Srov. bod 4 anotovaného rozhodnutí.

47 Srov. bod 23 anotovaného rozhodnutí.

48 Viz bod 25 anotovaného rozhodnutí.
} 
tifikovatelný pouze na základě registrační značky z důvodu jejího zápisu do registru vozidel a takováto značka je pak osobním údajem. ${ }^{49}$ Vlastník vozidla a provozovatel je nepřímo identifikovatelný prostřednictvím vozidla, nebơt to je $\mathrm{v}$ daný okamžik spjato právě s konkrétním vlastníkem a provozovatelem. ${ }^{50}$ Je nezbytné ale vzít v potaz fakt, že registrační značka je osobním údajem pouze $\mathrm{v}$ prrípadě, kdy se vztahuje $\mathrm{k}$ určité fyzické osobě jako provozovateli nebo vlastníka vozidla. ${ }^{51}$

Přestože byl právní závěr krajského soudu korigován, tak Nejvy̌̌ší správní soud konstatoval, že $\mathrm{v}$ tomto případě nedošlo $\mathrm{k}$ přímému zasažení do práv žalobce, nebở zásah nebyl dostatečně individualizován. Pouhá znalost registrační značky není kvalifikovaným zájmem, který by odůvodnil žádost o další údaje z registru vozidel, pomocí kterých by došlo k ztotožnění stěžovatele. ${ }^{52}$ Nejvyšší správní soud tedy dospěl k závěru, že kasační stížnost není důvodná a zamítnul ji.

Autorka: IK

\section{PŘÍPUSTNOST PŘEDÁVÁNÍ PROVOZNÍCH A LOKALIZAČNÍCH ÚDAJŮ ZPRAVODAJSKÝM SLUŽBÁM}

Soud: $\quad$ Soudní dvůr Evropské unie

Věc: $\quad$ C-623/17 (Privacy International)

Datum: $\quad$ 6. 10.2020

Dostupnost: curia.europa.eu

Spor mezi nevládní organizací Privacy International a zpravodajskými službami Spojeného království (GCHQ ${ }^{53} M I 5^{54}$ a $\left.M I 6^{55}\right)$, se týkal zákonnosti ná-

\footnotetext{
49 Viz bod 30 anotovaného rozhodnutí.

50 Srov. bod 31 anotovaného rozhodnutí.

51 Srov. bod 33 anotovaného rozhodnutí.

52 Srov. bod 39 anotovaného rozhodnutí.

53 Tzn. Government Communications Headquarters.

54 Tzn. Security Service.

55 Tzn. Secret Intelligence Service.
} 
rodní právní úpravy umožňující hromadné získávání dat o komunikaci těmito složkami státu.

Žaloba na nezákonnost těchto postupů byla podána v roce 2015 a národní soud se jí zabýval jak z hlediska anglického práva, tak z hlediska EÚLP $^{56}$ a unijního práva. ${ }^{57}$ Shledal přitom dané postupy v souladu s národním právem a zajištěné přiměřenými opatřeními (opatření pro přístup $\mathrm{k}$ datům jinými subjekty, zpo̊soby získávání dat a zajištění nezávislého dohledu) pro soulad s čl. 8 EÚLP. ${ }^{58}$

Na Soudní dvưr se však obrátil v otázce dopadu unijního práva a použitelnosti závěrů z rozhodnutí C-203/15 a C-698/15, Tele2 Sverige, ${ }^{59}$ na tyto postupy zpravodajských služeb. ${ }^{60}$ Předmětem rozhodnutí tak byl výklad čl. 1 odst. 3 a čl. 15 odst. 1 směrnice 2002/58/ES ${ }^{61}$ ve znění směrnice 2009/136/ES s přihlédnutím k čl. 4 odst. 2 SEU $^{62}$ a čl. 7, 8 a 52 odst. 1 LZPEU. $^{63,64}$

Ohledně dopadu unijního práva na tuto problematiku Soudní dvůr po podrobné analýze ${ }^{65}$ dospěl k závěru, že pro výklad nelze aplikovat předchozí judikaturu vztahující se ke směrnici $95 / 46 / \mathrm{ES}^{66}$ a že veškeré zpracování osobních údajů ze strany poskytovatelů služeb elektronických komunikací spadá pod rámec směrnice 2002/58/ES, včetně zpracování v důsledku po-

\footnotetext{
56 Evropská úmluva o ochraně lidských práv.

57 Srov. bod 20 anotovaného rozhodnutí.

58 Bod 21 anotovaného rozhodnutí.

59 Rozsudek SDEU ze dne 21.12.2016, Tele2 Sverige, C-203/15 a C-698/15, ECLI:EU:C:2016:970.

60 Body 22 a 29 anotovaného rozhodnutí.

${ }^{61}$ Směrnice Evropského parlamentu a Rady 2002/58/ES ze dne 12. července 2002 o zpracování osobních údajů a ochraně soukromí v odvětví elektronických komunikací (Směrnice o soukromí a elektronických komunikacích).

62 Smlouva o Evropské unii.

63 Listina základních práv Evropské unie.

64 Bod 1 anotovaného rozhodnutí.

65 Body 37-39 a 42 anotovaného rozhodnutí.

66 Směrnice Evropského parlamentu a Rady 95/46/ES ze dne 24. října 1995 o ochraně fyzických osob v souvislosti se zpracováním osobních údajů a o volném pohybu těchto údajů (již není platná).
} 
vinností uložených orgány veřejné moci. ${ }^{67}$ I na národní právní předpis umožňující požadovat od těchto poskytovatelů sdílení provozních a lokalizačních údajů se zpravodajskými službami za účelem zajištění národní bezpečnosti tak $\mathrm{v}$ tomto směru dopadá unijní právo. ${ }^{68} \mathrm{~V}$ návaznosti na tento závěr se Soudní dvůr zabýval druhou předběžnou otázkou, která se týkala použitelnosti závěrů výše zmíněného rozhodnutí, které př̌edně brání národnímu zákonodárci ukládat poskytovatelům služeb elektronických komunikací obecné a neselektivní předávání provozních a lokalizačních údajů zpravodajským službám. ${ }^{69}$ Po podrobné analýze aplikovatelnosti svých dř́vějších úvah Soudní dvưr dospěl k závěru o nepřípustnosti výjimky v tomto směru narušující princip zajištění důvěrnosti elektronické komunikace a tedy potvrzení aplikovatelnosti závěrů své výše zmíněné judikatury.

Rozhodnutí je zvláště zajímavé ve dvou směrech. Zaprvé utvrzuje striktní pozici Soudního dvora proti plošným nástrojům sledování elektronické komunikace (data retention) bez ohledu na př́ijemce (zpravodajské služby) a účel (národní bezpečnost). Zadruhé vytváří směrodatné pravidlo pro ostatní členské státy, byt pro strany daného sporu má vzhledem k vývoji Brexitu závěr Soudního dvora značně nejistou váhu.

Autor: FK

\section{POŘÍZENÍ SKRYTÉHO ZÁZNAMU NA PRACOVIŠTI NEMUSÍ PORUŠIT PRÁVO NA SOUKROMÍ}

Soud: $\quad$ Evropský soud pro lidská práva

Datum: $\quad$ 17. 10. 2019

Věc: $\quad$ Spojené žádosti 1874/13 a 8567/13 (López Ribalda a další proti Španělsku)

Dostupnost: hudoc.echr.coe.int

\footnotetext{
${ }^{67}$ Bod 46 anotovaného rozhodnutí.

68 Bod 49 anotovaného rozhodnutí.

69 Bod 50 anotovaného rozhodnutí.
} 
Stěžovatelé, López Ribalda a ostatní, byli ve Španělsku propuštěni ze supermarketu. ${ }^{70}$ Kvůli krádežím nainstaloval zaměstnavatel bezpečnostní kamery, veřejné, které byly označeny, a skryté, zabírající i prostory za pokladnou $^{71} \mathrm{Na}$ základě videozáznamu došlo k propouštění 14 zaměstnanců, včetně stěžovatelů, někteří podepsali dohodu o vyrovnání. ${ }^{72}$

Stěžovatelé zahájili řízení pro neoprávněné propuštění u pracovního tribunálu. ${ }^{73} \mathrm{U}$ stěžovatelů 1 a 2 zkoumal tribunál přípustnost důkazu pomocí videozáznamu, neshledal porušení práva na soukromí podle čl. 24 španělské ústavy, ${ }^{74}$ protože zásah byl proporční k ochraně zaměstnavatelových zájmů. ${ }^{75} \mathrm{U}$ stěžovatelů 3,4 a 5 soud posoudil pouze legalitu dohody o vyrovnání. ${ }^{76}$ Stěžovatelé podali odvolání ke španělskému Nejvyššímu soudu pro absenci předchozího oznámení o sledování. Soud uvedl, že zaměstnavatel postupoval podle španělského zákoníku práce a ten takové oznámení nevyžaduje. ${ }^{77}$ Stěžovatelé se dále obrátili opět na Nejvyšší soud a následně i na španělský Ústavní soud, u obou bylo podání odmítnuto. ${ }^{78}$

Stěžovatelé rozporovali soulad s právem na soukromí podle čl. 8 Úmluvy o ochraně lidských práv. ESLP zkoumal legislativu a judikaturu ve Španělsku. Španělský ústavní soud stanovil ve věci sledování na pracovišti třístupňový test. ${ }^{79,80}$ Později rozhodl, že permanentnímu sledování už musí předcházet notifikace ${ }^{81}$ a informace o přibližném rámci záběru kamery. ${ }^{82}$

ESLP rozhodoval, zda došlo $\mathrm{k}$ porušení práva na spravedlivý proces (čl. 6 Úmluvy) a práva na soukromí (čl. 8 Úmluvy). ESLP neshledal poru-

\footnotetext{
70 Bod 3 a 10 anotovaného rozhodnutí.

71 Bod 11 a 12 anotovaného rozhodnutí.

72 Bod 17 anotovaného rozhodnutí.

73 Tzn. Granollers Employment Tribunal no. 1.

74 Bod 25 anotovaného rozhodnutí.

75 Body 25 až 28 anotovaného rozhodnutí.

76 Body 29 až 30 anotovaného rozhodnutí.

77 Bod 33 anotovaného rozhodnutí.

78 Bod 39 anotovaného rozhodnutí.

79 Tzn. Oprávněný zájem, nezbytnost a proporcionalita.

80 Bod 54 anotovaného rozhodnutí.

81 Bod 57 anotovaného rozhodnutí.

82 Bod 59 anotovaného rozhodnutí.
} 
šení v řízení jako celku. ${ }^{83}$ Při posuzování otázky soukromí podle ustálených kritérii $^{84}$ shledal, že $\mathrm{v}$ předmětné době mělo španělské právo podrobná pravidla pro ochranu soukromí a ta nebyla porušena. ${ }^{85}$ Během řízení před španělskými soudy byl důsledně vyhodnocen konflikt zájmů. ${ }^{86}$ Nedostatečná informovanost stěžovatelů o sledování je relevantním faktorem, avšak záznam byl použit jenom $\mathrm{k}$ jednomu účelu - odhalení krádeží - a toho nešlo dosáhnout jinak. ${ }^{87}$ Užití videozáznamu bylo v souladu s principem proporcionality. ${ }^{88}$

ESLP tak zamítl žádost stěžovatelů a neshledal porušení lidských práv ze strany Španělska. ${ }^{89}$ Rozhodnutí je zajímavé z hlediska nastavení limitů práva na ochranu soukromí.

Autorka: VŽ

\section{PRÁVO NA INFORMACE}

\section{APLIKAČNÍ RÁMEC PSI SMĚRNICE}

Soud: $\quad$ Soudní dvůr Evropské unie

Věc: $\quad$ C-215/17 (NKBM)

Datum: $\quad$ 14. 11. 2018

Dostupnost: curia.europa.eu

Slovinská novináŕka požádala tamní banku NKBM o informace o smlouvách, které tato banka uzavřela mezi roky 2012 a 2014 s poradenskými společnostmi a advokátními kancelářemi. $\mathrm{V}$ této době, stejně jako $\mathrm{v}$ době žádosti, byla NKBM pod dominantním vlivem subjektu veřejného práva, protože Slovinská republika vlastnila většinu jejího kapitálu. ${ }^{90}$ NKBM od-

\footnotetext{
83 Body 153 až 161 anotovaného rozhodnutí.

84 Bod 116 anotovaného rozhodnutí.

85 Bod 119 anotovaného rozhodnutí.

86 Body 121 až 124 anotovaného rozhodnutí.

87 Body 128 až 131 anotovaného rozhodnutí.

88 Body 132 až 134 anotovaného rozhodnutí.

89 Bod 137 a 161 anotovaného rozhodnutí.

90 Bod 18 anotovaného rozhodnutí.
} 
mítla informace poskytnout $\mathrm{z}$ důvodu ochrany obchodního tajemství a postupně se bránila soudně, až na úroveň slovinského Nejvyššího soudu, který předložil předběžnou otázku SDEU.

Slovinský zákon zakládal povinnost poskytnout informace, které byly věcně byly předmětem původního sporu, i v případech, kdy veřejný zájem na jejich poskytnutí nepřevažuje nad zájmem povinných subjektů na jejich nezveřejnění. ${ }^{91}$ NKBM argumentovala tím, že v důsledku aplikace evropského práva, zejména čl. 1 odst. 2 písm. c) třetí odrážka směrnice 2003/98/ES (ve znění směrnice 2013/37/EU; dále PSI směrnice) a čl. 432 odst. 2 nařízení EU č. 575/2013, není možné informace poskytnout. Prvně jmenované ustanovení totiž zakládá výjimku z aplikace směrnice, když uvádí, že „směrnice se nepoužije na dokumenty, které nejsou př̌stupné podle režimů př́stupu $v$ členských státech, včetně z důvodů obchodní důvěrnosti (např. obchodního, profesního nebo firemního tajemství)“. Druhé ustanovení zakládá obdobnou výjimku z poskytování informací v kontextu nařízení č. 575/2013. Předkládací soud proto se proto ve své předběžné otázce ptal, zda uvedená evropská úprava brání členskému státu v zavedení širší informační povinnosti, jako tomu bylo $\mathrm{v}$ hodnoceném případě.

SDEU zkraje své argumentace konstatoval, že PSI směrnice stanoví minimální soubor pravidel pro opakované užití informací veřejného sektoru. ${ }^{92}$ SDEU pak po aplikaci čl. 2 bod. 2 písm. a) až c) PSI směrnice dospěl k závěru, že NKBM není veřejnoprávním subjektem, a proto se na ni aplikace směrnice nevztahuje. ${ }^{93}$ Obdobně pak $\mathrm{v}$ př́padě aplikace nařízení č. 575/2013 dospěl SDEU k závěru, že předmětná právní úprava reguluje povinnost jednou ročně poskytovat určité informace, tedy jinou situaci, než která byla předmětem sporu, kde šlo o žádost. ${ }^{94} \mathrm{~V}$ důsledku toho evropská právní úprava nikterak neovlivňuje hodnocenou úpravu národní.

Z hlediska problematiky PSI jde o připomenutí, že PSI směrnice nezakotvuje právo na přístup $\mathrm{k}$ informacím veřejného sektoru, ale „počitá $s$ existen-

\footnotetext{
91 Bod 21 anotovaného rozhodnutí.

92 Bod 26 anotovaného rozhodnutí.

93 Body 27 a 28 anotovaného rozhodnutí.

94 Body 38 a 39 anotovaného rozhodnutí.
} 
cí takového práva v platných právních předpisech členských států, takže pravidla a postupy týkající se př́stupu $k$ těmto informacím nespadají do její působnosti. “95

Autor: JM

\section{NEOPRÁVNENÉ BLOKOVANIE WEBOVEJ STRÁNKY PROSTREDNÍCTVOM IP ADRESY}

Soud: $\quad$ Európsky súd pre l’udské práva

Věc: $\quad$ Žiadost' 10795/14 (Vladimir Kharitonov proti Rusku)

Datum: $\quad$ 23. 6. 2020

Dostupnost: hudoc.echr.int

Pán Kharitonov prevádzkuje webovú stránku (digital-books.ru), na ktorej uverejňuje správy o distribúcií elektronických kníh. Na prevádzku využíva služby zdiel’aného úložiska DreamHost. Iná webová stránka (rastaman.tales.ru), obsahuje l’udové príbehy o kanabise a je uložená na rovnakom úložisku. Osobitostou úložiska je, že uložené stránky síce používajú unikátne doménové mená, avšak zdiel’ajú rovnakú IP adresu. Ruské úrady vyhodnotili, že obsah stránky o kanabise porušuje zákon a operátor Roskomnadzor zablokoval jej IP adresu. V dôsledku blokovania prostredníctvom IP adresy však došlo aj k zablokovaniu stránky pána Kharitonova. Moskovský súd jeho staažnost̉ zamietol, pričom len uviedol, že operátor Roskomnadzor pri výkone príkazu konal v rámci svojich kompetencií a v súlade so zákonom. ${ }^{96}$ Dopady príkazu na webovú stránku pána Kharitonova neposudzoval.

Po vyčerpaní opravných prostriedkov sa pán Kharitonov obrátil na Európsky súd pre l’udské práva (ESL’P) aby určil, že blokovanie IP adresy malo na neho neprimeraný vedl'ajší účinok ${ }^{97}$ a viedlo porušeniu jeho práva

\footnotetext{
95 Bod 32 anotovaného rozhodnutí.

96 Bod 8 anotovaného rozhodnutia. Blokovanie malo údajne byt odôvodnené zamedzením prístupu k informáciám o výrobe a užívaní drog.

97 Z angl. „disproportionate collateral effect“.
} 
na slobodu prejavu (čl. 10 Dohovoru) ${ }^{98}$ a práva na účinný ochranný prostriedok (čl. 13 Dohovoru).

Vnútroštátny predpis nevyžadoval, aby operátor Roskomnadzor pred vykonaním príkazu skúmal, či IP adresu využíva viacero webových stránok ${ }^{99}$ ani či účinky blokovania sú proporcionálne, teda či je blokovaný len nelegálny obsah. Zákon neumožňoval stažovatel’ovi oboznámit sa s obsahom príkazu a súdy sa obmedzili len na posúdenie kompetencie operátora príkaz vykonat'. ESL'P s odkazom na čl. 10 ods. 2 Dohovoru uviedol, že zásah predstavuje porušenie Dohovoru nie je „stanovený zákonom“ a nesleduje niektorý z legitímnych ciel'ov, ktorých dosiahnutie je „nevyhnutné v demokratickej spoločnosti“.

Podl'a ESL'P stažovatel' nemal žiaden vztah k blokovanej stránke ani nezodpovedal za jej obsahu a preto blokovanie nemohlo byt' založené na ustanovení zákona, ktoré malo byṫ jeho právnym základom. ${ }^{100}$ Stažovatel' podl'a ESL’P znášal nežiadúce následky blokovania výlučne z dôvodu totožnosti IP adresy $s$ webovou stránkou obsahujúcou nelegálny obsah. ${ }^{101}$ Ked’že zákon neposkytoval stažovatel'ovi dostatočné právne záruky ochrany pred excesívnymi a arbitrárnymi účinkami príkazu, podla ESL’P nespĺn̆al Dohovorom predpokladanú podmienku predvídatel’nosti účinkov, teda neumožnil stažovatel'ovi regulovat svoje správanie a zásah vo forme blokovania preto nebol „stanovený zákonom“102 ako to vyžaduje čl. 10 Dohovoru. ${ }^{103}$

Na tomto základe následne ESLPP konštatoval porušenie čl. 10 aj 13 Dohovoru. ${ }^{104}$

Autor: JVi

${ }^{98}$ Európsky dohovor o ochrane ludských práv a základných slobôd. Uvedené právo podla Dohovoru zahŕňa aj právo „zastavat názory a prijímat a rozširovat informácie alebo myšlienky bez zasahovania štátnych orgánov“.

99 Napríklad prostredníctvom bežne dostupných nástrojov akým je tzv. reverzné prehladanie IP adresy (,reverse IP lookup“), ktoré umožňuje zistit zoznam webových stránok uložených na rovnakom serveri.

${ }^{100}$ Bod 39 anotovaného rozhodnutia.

${ }^{101}$ Bod 42 anotovaného rozhodnutia.

${ }^{102} \mathrm{Z}$ angl. „prescribed by law“.

${ }^{103}$ Bod 46 anotovaného rozhodnutia. 


\section{OSTATNí}

\section{PROSTOROVÉ ODPOSLECHY JE MOŽNO VYUŽÍT I V JINÝCH PŘÍPADECH, NEŽ PRO KTERÉ BYLY NAŘÍZENY}

$\begin{array}{ll}\text { Soud: } & \text { Nejvyšší soud } \\ \text { Věc: } & 7 \text { Tdo } 865 / 2020 \\ \text { Datum: } & 1.9 .2020 \\ \text { Dostupnost: } & \text { nsoud.cz }\end{array}$

České soudy se postupně zabývaly případem, kdy se dva př́slušníci Policie České republiky při objasňování a prověřování trestné činnosti podezřelého ve vzájemné součinnosti od tohoto podezřelého snažili vymámit doznání ke spáchání dalšího trestného činu a opatřit tak důkazní materiál k zahájení trestního stíhání i pro trestnou činnost, za kterou nebyl podezřelý usvědčován jinými důkazy. ${ }^{105} \mathrm{~V}$ rámci výslechu byly využity prostorové odposlechy (na základě $§ 158$ d trestního řádu - sledování osob a věcí). Ty ale nebyly schváleny soudem pro prokázání spáchání trestné činnosti policistů.

Daným případem se postupně zabývaly nižší soudy. Řešily, jestli došlo k naplnění skutkové podstaty zneužití pravomoci úřední osoby, zneužití bezbrannosti a tísně podezřelého atd. ze strany zmíněných policistů. Zabývaly se ale rovněž důkazní použitelností prostorových odposlechů, které v dané věci tvořily významnou část provedeného dokazování. ${ }^{106}$ Na ty se dále primárně zaměříme.

\footnotetext{
${ }^{104}$ Porušenie čl. 10 aj 13 Dohovoru bolo jednohlasne konštatované, avšak rozhodnutie obsahuje spoločné odlišné stanovisko troch sudcov komory. Aj títo sudcovia zastávajú názor, že zásah nebol „stanovený zákonom“, avšak nie z dôvodu, že zákonná úprava nespíňala kritérium predvídatelnosti, ale z dôvodu, že zásah nemal vo vnútroštátnom predpise právny základ („But unlike our colleagues, we believe that this is so because the interference had no basis in domestic law, not because the law did not satisfy the foreseeability requirement."). Táto čast' sudcov si teda nemyslí, že vnútroštátny predpis je nekompatibilný s Dohovorom a bude potrebná jeho zmena, ale tvrdí že na nápravu by postačovala zmena administratívnej praxe (na úrovni operátora Roskomnadzor) a súdnej praxe (na úrovni domácich súdov), teda bez legislatívnej intervencie.

${ }^{105}$ Bod 2 anotovaného rozhodnutí.

${ }^{106}$ Bod 28 anotovaného rozhodnutí.
} 
Právě procesní použitelnost záznamů o sledování osob a věcí se stala klíčovou otázkou pro Nejvyšší soud, který řešil, jestli nařízené odposlechy lze použít i v jiné trestní věci, než je ta, v níž bylo sledování provedeno. Nejvyšší soud tak zkoumal zejména vzájemné postavení jednotlivých odstavců § 158d trestního řádu, kdy se část odborné veřejnosti kloní k tomu, že daným způsobem pořízený důkaz nelze použít $v$ jiné trestní věci. Soud nicméně zdůraznil, že takový výklad „by představoval nelogický anachronismus, pokud by jakékoli záznamy ze sledování povoleného soudcem $v$ jiné věci byly důkazně vyloučeny, $i$ když by poskytovaly zásadní důkazní materiál o těch nejzávažnějších zločinech. “107 Dále soud uvedl, že by protichůdný výklad byl v logickém rozporu s $\S 88$ odst. 6 trestního řádu, který explicitně (ale za stanovení konkrétních podmínek) s užitím odposlechu v jiné trestní věci počítá.

Nejvyšší soud tak rozhodl (a zrušil předchozí rozhodnutí nižších soudů), že záznamy o sledování osob a věcí dle § 158d lze použít jako důkaz i v jiné trestní věci, než je ta, v níž bylo sledování povoleno, „je-li $i$ v této věci vedeno ř́zení o úmyslném trestném činu nebo souhlasí-li s tím osoba, do jejǐz práv a svobod bylo sledováním zasahováno. “108 Přípustnost takového důka$\mathrm{zu}$ je nutno posuzovat zejména $\mathrm{v}$ souvislosti s respektem na ochranu soukromí dané osoby, vzhledem $\mathrm{k}$ dané situaci (tedy že se jednalo o policisty ve výkonu služby) však nebyla využitelnost důkazu v rozporu s ochranou soukromí.

Soud tak v dané věci vymezil, jakým způsobem lze využít důkazů získaných na základě prostorových odposlechů i v jiné trestní věci. Upozorňujeme však, že neinterpretoval použitelnost odposlechů telekomunikačního provozu (dle $\S 88$ trestního řádu), což bylo mnohdy mylně pochopeno médii.

Autor: PL

\footnotetext{
107 Bod 60 anotovaného rozhodnutí.

${ }^{108}$ Bod 54 anotovaného rozhodnutí.
} 


\title{
K POSOUZENÍ NARUŠENÍ INTERNETOVÉ NEUTRALITY POSKYTOVATELEM SLUŽEB INTERNETU
}

\author{
Soud: $\quad$ Soudní dvůr Evropské unie \\ Datum: $\quad$ 15. 9. 2020 \\ Věc: $\quad$ Spojené věci C-807/18 a C-39/19 (Telenor Magyarország) \\ Dostupnost: curia.europa.eu
}

Mad’arský soud ${ }^{109}$ podal předběžnou otázku týkající se tzv. nulového tarifu, ${ }^{110}$ kdy je v rámci objemu dat zvýhodňována určitá aplikace nebo služba. Vzešla $\mathrm{z}$ řízení Telenor ${ }^{111}$ proti mad’arskému úřadu pro komunikace a média (NÚKM) ${ }^{112}$ Telenor poskytuje služby př́stupu $\mathrm{k}$ internetu a dva balíčky služeb nazvané MyChat a MyMusic, ${ }^{113}$ u kterých NÚKM konstatoval, že porušují neutralitu internetu. ${ }^{114}$ SDEU posuzoval soulad opatření NÚKM s nařízením 2015/2020 o přístupu k otevřenému internetu. ${ }^{115,116}$

NÚKM rozhodl, že služby Telenoru odporují čl. 3 odst. 3 nařízení 2015/2020. ${ }^{117}$ Telenor rozhodnutí napadl s odvoláním na to, že ke zvýhodnění nedochází jednostranně, ale na základě dohody s koncovými uživateli. ${ }^{118}$

\footnotetext{
109 Tzn. Fővárosi Törvényszék - soud hlavního města Budapešti, Mad’arsko.

${ }^{110}$ Tzv. zero rating

111 Tzn. Telenor Magyarország Zrt.

112 Tzn. Nemzeti Média- és Hírközlési Hatóság Elnöke.

113 Bod 9 anotovaného rozhodnutí.

${ }^{114}$ Bod 12 anotovaného rozhodnutí.

115 Nařízení Evropského parlamentu a Rady (EU) 2015/2120 ze dne 25. listopadu 2015, kterým se stanoví opatření týkající se přístupu $\mathrm{k}$ otevřenému internetu a mění směrnice 2002/22/ES o univerzální službě a právech uživatelů týkajících se sítí a služeb elektronických komunikací a nařízení (EU) 531/2012 o roamingu ve veřejných mobilních komunikačních

${ }^{116}$ Bod 1 a 2 anotovaného rozhodnutí.

117 Bod 13 anotovaného rozhodnutí.

118 Bod 15 anotovaného rozhodnutí.
} 
Předkládající soud se ptal, zda musí být na dohodu nahlíženo z hlediska čl. 3 odst. 2 nebo odst. 3 nařízení $2015 / 2020$ a zda má vliv dopad na trh. ${ }^{119}$ Soud postrádal v nařízení metodiku. ${ }^{120}$

Nařízení 2015/2020 stanovuje princip internetové neutrality, ${ }^{121}$ pro řízení jsou relevantní pravidla v čl. 3, že uživatelé mají přístup k obsahu bez ohledu na jejich polohu, poskytovatele či původ apod. (odst. 1) a tato práva nelze omezit obchodní praktikou či dohodou (odst. 2). ${ }^{122}$ Odst. 3 stanovuje zákaz diskriminace při poskytování služeb a přípustné výjimky pro opatření řízení provozu. ${ }^{123}$

Slučitelnost dohody podle čl. 3 odst. 2 s odst. 1 je potřeba vždy posoudit individuálně podle dopadu. ${ }^{124}$ Kumulace uzavřených dohod o zvýhodnění v rámci objemu dat ovlivňuje využívání konkrétních aplikací a služeb na trhu. ${ }^{125}$ Pokud se tak děje na podstatné části trhu, dohody mohou omezit právo dle odst. $1 .{ }^{126}$ Oproti tomu pro aplikaci odst. 3 není dle SDEU třeba posoudit dopad na $\operatorname{trh}^{127}$ a v případě tarifních balíčků Telenoru je diskriminace dána obchodním cílem opatření a není uplatnitelná žádná z výjimek. $^{128}$

Rozsudek stanovil neslučitelnost této obchodní praktiky s čl. 3 odst. 2 i odst. 3 nařízení 2015/2020. Rozsudek poskytuje cenná vodítka pro posouzení srovnatelných situací v budoucnu.

Autorka: VŽ

\footnotetext{
${ }^{119}$ Bod 20 anotovaného rozhodnutí.

${ }^{120}$ Bod 19 anotovaného rozhodnutí.

${ }^{121}$ Bod 3 anotovaného rozhodnutí.

${ }^{122}$ Bod 6 anotovaného rozhodnutí.

123 Tamtéž.

${ }^{124}$ Bod 43 anotovaného rozhodnutí.

${ }^{125}$ Bod 44 anotovaného rozhodnutí.

${ }^{126}$ Bod 45 a 46 anotovaného rozhodnutí.

${ }^{127}$ Body 49 až 51 anotovaného rozhodnutí.

${ }^{128}$ Body 52 a 53 anotovaného rozhodnutí.
} 
Toto dílo lze užít v souladu s licenčními podmínkami Creative Commons BY-SA 4.0 International (http://creativecommons.org/licenses/by-sa/4.0/legalcode). 